\title{
Kuat Tekan dan Porositas Beton menggunakan Air Gambut dan Kapur Tohor untuk Konstruksi di Lingkungan Gambut
}

\author{
Hagus Tizia 1 , Monita Olivia ${ }^{2}$, Edy Saputra ${ }^{3}$ \\ ${ }^{1,2}$ Program Studi Magister Teknik Sipil Universitas Riau \\ ${ }^{3}$ Program Studi Magister Teknik Kimia Universitas Riau \\ Email: agustizia@yahoo.co.id, *monitaolivia@gmail.com (corresponding author), \\ edysaputra_eng@yahoo.com
}

\begin{abstract}
ABSTRAK
Air gambut banyak ditemukan di daerah lahan gambut atau dataran rendah di Sumatera, khususnya di Kabupaten Bengkalis. Air gambut berwarna coklat tua kehitaman, memiliki kadar organik tinggi dan memiliki kemasaman tinggi. Pada umumnya di daerah terpencil di pulau Bengkalis dengan sumber air bersih terbatas maka air gambut sering digunakan sebagai air pencampur beton. Air gambut juga dipakai sebagai air perawatan beton, padahal karakteristik air gambut tidak memenuhi persyaratan sebagai air bersih. Pada penelitian ini dilakukan kajian kuat tekan dan porositas beton menggunakan air gambut yang belum diolah dan telah diolah dengan kapur tohor. Kapur tohor $(\mathrm{CaO})$ digunakan sebanyak 0,05 g/l dan dilarutkan selama 5-10 menit sehingga menghasilkan air dengan $\mathrm{pH}$ 7. Beton yang direncanakan menggunakan pengikat Ordinary Portland Cement (OPC) dan Portland Composite Cement (PCC) dengan kuat tekan rencana sebesar 20 MPa pada umur 28 hari. Sebagai kontrol digunakan benda uji yang dibuat menggunakan air biasa sebagai air pencampur. Benda uji dibuat dengan air gambut yang telah diberi kapur tohor dan setelah dicetak benda uji direndam langsung di saluran air gambut di Kabupaten Bengkalis. Hasil penelitian menunjukkan bahwa kuat tekan beton OPC menggunakan air gambut-kapur tohor (OPC-K) meningkat selama umur perendaman hingga 150 hari. Sedangkan beton PCC air gambut-kapur tohor (PCC-K) terus mengalami peningkatan kuat tekan hingga umur 91 hari tetapi terjadi penurunan kekuatan hingga umur 150 hari. Beton kontrol OPC memperlihatkan penurunan kuat tekan setelah perendaman, tetapi beton kontrol PCC menunjukkan kenaikan kekuatan. Porositas beton OPC-K terus meningkat pada umur 150 hari, sedangkan pada beton PCC-K terjadi penurunan porositas yang cukup signifikan. Penggunaan air gambut dengan kapur tohor sebagai air pencampur dapat memperbaiki kuat tekan dan porositas beton OPC dan PCC yang terpapar air gambut dalam jangka panjang.
\end{abstract}

Kata Kunci: air gambut, kapur tohor, kuat tekan, porositas, semen

\begin{abstract}
Peat water is often found in peat environment and low land in Sumatera, especially in Bengkalis Regency. Peat water has a dark brownish colour, has a high organic content and low acidity. Peat water is generally used in a remote area in Bengkalis Regency as concrete mixing water. Peat water is also used as curing water, although the peat water characteristics are not in comply as clean water. In this research, compressive strength and porosity of concrete using untreated and treated water with lime were studied. The lime used was $0.05 \mathrm{~g} / \mathrm{l}$ and dissolved for about 5-10 minutes to produce water with a $\mathrm{pH}$ of 7 . The concrete used binder from Ordinary Portland Cement (OPC) and Portland Cement Composite (PCC) with a target strength of $20 \mathrm{MPa}$ at 28 days. As a control, the samples made using freshwater as mixing water. The samples were produced using peat water with lime, and after cast, the samples were immersed in an open channel in Bengkalis Regency. Results show that the compressive strength of concrete using treated peat water (OPC-K) increased during immersion age of 150 days. While the PCC-K concrete strength was increased up to 91 decreased at 150 days. The OPC concrete shows a decrease of compressive strength after immersion, but the PCC shows a different trend. The porosity of OPC-K concrete increased steadily until 150 days, but the porosity of PCC-K concrete decreased significantly. The use of peat water treated with lime as mixing water could improve the compressive strength and porosity of the OPC and PCC exposed to the peat water.
\end{abstract}

Keywords: cement, compressive strength, lime, peat water, porosity

Haguz, Kuat Tekan dan Porositas Beton menggunakan Air Gambut dan Kapur Tohor untuk Konstruksi di Lingkungan Gambut 


\section{PENDAHULUAN}

Berbagai wilayah di Provinsi Riau, salah satunya Kabupaten Bengkalis, mayoritas terdiri dari lahan gambut. Gambut yang terdapat di wilayah tersebut cukup tebal dengan kedalaman sekitar 200$300 \mathrm{~cm}$. Menurut Nasrul [1], Kedalaman lahan gambut di Kabupaten Bengkalis adalah 0-50 cm (lahan bergambut), $50-100 \mathrm{~cm}$ (gambut dangkal), $100-200 \mathrm{~cm}$ (gambut pertengahan), $200-300 \mathrm{~cm}$ (gambut dalam), dan lebih dari $300 \mathrm{~cm}$ (gambut sangat dalam). Pada lahan gambut banyak terdapat genangan air, kanal dan ceruk kecil berisi air gambut. Air gambut memiliki $\mathrm{pH}$ rendah <4,5, kadar organik tinggi akibat sisa tumbuhan terdekomposisi, dan berwarna merah kehitaman [2]. Gambut bersifat asam karena mengandung asam humat dan asam sulfat. Senyawa asam organik tersebut merupakan hasil pelapukan lignin dan oksidasi mineral sulfat seperti pirit [3].

Beton harus memiliki kualitas dan durabilitas tinggi agar memiliki ketahanan di lingkungan asam. Untuk lingkungan tertentu, digunakan semen khusus yang tahan lingkungan asam seperti semen tipe $\mathrm{V}$ maupun semen Portland Composite Cement (PCC). Penelitian menggunakan semen PCC untuk lingkungan gambut telah pernah dikaji [4]. Selain menggunakan beton dengan semen khusus yang tahan di lingkungan asam, terdapat penelitian bertujuan mengurangi pemakaian semen pada beton telah banyak dilakukan dengan tidak menghilangkan kekuatan beton tersebut. Penggunaan abu sawit dan abu terbang yang berasal dari limbah agro-industri dapat meningkatkan kekuatan dan menurunkan porositas beton setelah direndam di lingkungan gambut dalam jangka waktu tertentu $[5,6]$. Reaksi pozzolanik berperan dalam meningkatkan ketahanan beton tersebut meskipun direndam dalam lingkungan gambut lebih dari 91 hari.

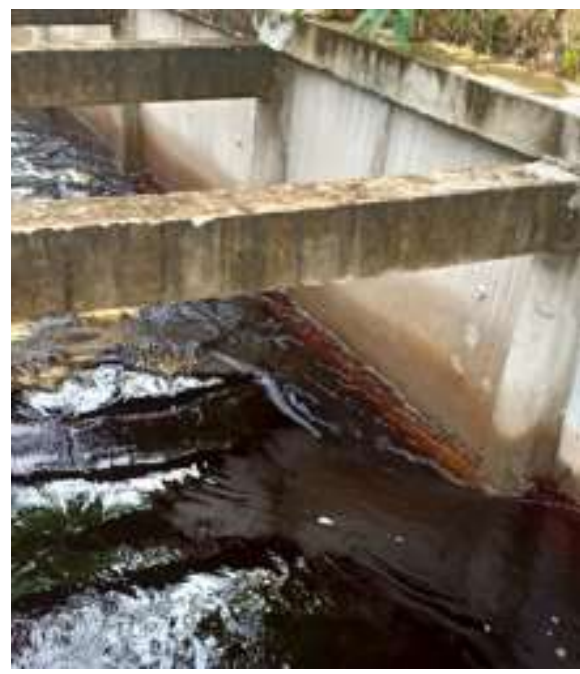

Gambar 1. Air gambut pada saluran terbuka di Kabupaten Bengkalis.
Konstruksi beton yang dibangun di pulau Bengkalis, seperti perkerasan kaku dan saluran drainase umumnya terletak di daerah terpencil yang sulit mendapatkan air bersih. Di daerah-daerah tersebut umumnya hanya tersedia air gambut yang mengalir maupun tergenang seperti pada Gambar 1 . Pada saat pelaksanaan pembangunan konstruksi beton karena keterbatasan air bersih, maka air yang banyak tersedia di lapangan seperti air gambut sering dipakai sebagai air pencampur beton. Padahal penggunaan air gambut sebagai air pencampur tidak memenuhi syarat dan dapat mengganggu proses hidrasi semen karena kandungan organik dalam air gambut.

Menurut Mulyono [7], air untuk campuran beton harus bersih dan tidak boleh mengandung minyak, alkali, zat organik, atau bahan lain yang dapat merusak beton. Berbagai penelitian penggunaan beton dengan air pencampur seperti air laut, air limbah tempat produksi ready mix, dan air limbah rumah tangga [8-10]. Hal ini perlu diperhatikan karena air yang tidak memenuhi persyaratan akan menyebabkan beton dengan ikatan lemah dan kekuatan tekan rendah. Pada umumnya beton yang dihasilkan akan memiliki waktu ikat awal lebih cepat dan kekuatan lebih rendah. Hal ini disebabkan karena air tidak bersih mengandung partikel solid sehingga menghasilkan berbagai reaksi kimia [10]. Agar air yang tidak memenuhi persyaratan dapat digunakan sebagai pencampur beton, maka air dapat ditambah dengan aditif untuk menetralkan zat-zat perusak pada beton. Penambahan zat aditif, yaitu melakukan pencampuran suatu bahan tambah yang mudah didapatkan ke dalam air gambut dengan perbandingan berat tertentu. Beberapa bahan tambah yang biasa digunakan untuk memperbaiki air gambut yaitu kapur tohor, tawas, dan kaporit.

Air gambut merupakan air yang tidak memenuhi persyaratan untuk sebagai air bersih. Penjernihan air gambut telah digunakan oleh masyarakat agar air gambut dapat digunakan untuk kebutuhan sehari-hari. Sebagai air pencampur beton, air gambut dapat dijernihkan menggunakan kapur tohor. Penelitian Rinanda et al. [11] menunjukkan penambahan kapur tohor dalam jumlah tertentu dapat mengurangi keasaman air gambut sehingga sebagai air pencampur dapat memperbaiki kekuatan beton. Meskipun secara umum $\mathrm{pH}$ air gambut dapat diperbaiki dengan penambahan kapur tohor, tetapi jumlah kapur tohor yang diperlukan berbeda-beda pada tiap lahan gambut. Oleh karena itu perlu didapatkan dosis efektif kapur tohor sehingga air tersebut dapat digunakan sebagai air pencampur beton pada konstruksi di Kabupaten Bengkalis.

Pada penelitian ini akan dikaji kuat tekan dan porositas beton dibuat dengan semen OPC (Ordinary Portland Cement) dan PCC (Portland Composite Cement) menggunakan air gambut dicampur dengan zat aditif kapur tohor sebagai air

Haguz, Kuat Tekan dan Porositas Beton menggunakan Air Gambut dan Kapur Tohor untuk Konstruksi di 
pencampur dan kemudian dirawat di saluran terbuka Kabupaten Bengkalis.

\section{TINJAUAN PUSTAKA}

Beton

Beton dibuat dengan dengan mencampur semen Portland dengan agregat halus, agregat kasar, air, dan aditif untuk mendapatkan campuran solid dan homogen dengan perbandingan tertentu. Campuran semen dan air akan menghasilkan reaksi kimia yang dapat mengikat agregat kasar dan halus membentuk massa keras seperti batu [12]. Kualitas beton ditentukan oleh berbagai faktor, seperti komposisi bahan penyusun, kualitas, ukuran dan jenis agregat, tipe semen, faktor air semen, jenis air, dan jenis aditif. Beton sebaiknya memiliki ketahanan tinggi di lingkungan agresif seperti air laut, asam, sulfat dan suhu tinggi. Metode pembuatan, perawatan beton, bahan penyusun, permeabilitas, porositas dan fase mikrostruktur termasuk berbagai faktor yang mempengaruhi durabilitas beton di lingkungan agresif tersebut [13].

\section{Air Pencampur Beton}

Air berperan penting sebagai pereaksi semen sehingga terjadi reaksi kimia yang menghasilkan produk hidrasi sehingga dapat mengikat pasir dan kerikil. Fungsi air juga untuk memberikan kemudahpengerjaan pada beton yang terdiri dari bahan-bahan kering seperti semen dan agregat [12]. Agar reaksi dapat berjalan dengan baik sehingga beton memiliki kekuatan tinggi, susut rendah dan keawetan, maka diperlukan air bersih sebagai air pencampur beton. Air pencampur beton harus memiliki kualitas seperti air minum sehingga tidak menimbulkan reaksi sampingan yang dapat merugikan kualitas beton.

Berdasarkan SNI 03-2847-2002 [14], air pencampur beton seharusnya tidak mengandung zatzat tidak bermanfaat seperti minyak, asam, alkali, garam dan bahan organik. Air tersebut tidak mengandung ion klorida lebih $0,5 \mathrm{~g} / \mathrm{l}$ dan sulfat lebih dari $1 \mathrm{~g} / \mathrm{l}$. Air yang tidak dapat diminum sebaiknya tidak digunakan sebagai air pencampur beton, kecuali memenuhi persyaratan bahwa komposisi bahan beton dibuat berdasarkan rancangan komposisi beton menggunakan air dari sumber yang sama. Persyaratan lain yang harus dipenuhi jika menggunakan air tidak layak adalah hasil pengujian kekuatan kubus mortar pada umur 7 dan 28 hari sekurang-kurangnya $90 \%$ dari kekuatan sampel menggunakan air layak minum.

Penelitian terdahulu beton yang menggunakan air pencampur bukan dari sumber air bersih, menunjukkan bahwa campuran beton akan memiliki waktu ikat lebih singkat dibandingkan beton biasa, memiliki ikatan lemah karena reaksi sampingan zat yang tidak baik untuk beton, mengurangi kuat tekan dan menurunkan kualitas beton secara signifikan $[8,15]$. Penggunaan air pencampur yang tidak sesuai persyaratan sebenarnya dapat membantu mengurangi kesulitan mendapatkan sumber air, tetapi akan merugikan kualitas beton untuk lingkungan agresif.

\section{Lingkungan Asam}

Reaksi kimia yang kompleks umumnya terjadi apabila beton berada di lingkungan asam. Asam akan melarutkan kalsium pada beton dan memberikan efek negatif berupa peningkatan porositas dan penurunan kekuatan tekan beton. Ada dua reaksi yang menjadi penyebab kerusakan beton di lingkungan asam [16]. Pada reaksi pertama terjadi antara kalsium hidroksida $\mathrm{Ca}(\mathrm{OH})_{2}$ dengan karbondioksida $\left(\mathrm{CO}_{2}\right)$ menghasilkan kalsium karbonat $\left(\mathrm{CaCO}_{3}\right)$ yang tidak larut dalam air. Ketika kalsium karbonat bereaksi dengan $\mathrm{CO}_{2}$ pada tahap selanjutnya maka akan terbentuk kalsium bikarbonat $\left(\mathrm{Ca}\left(\mathrm{HCO}_{3}\right)_{2}\right)$ yang lebih mudah larut dalam air.

Reaksi kedua akan terjadi sewaktu kalsium silikat hidrat $(\mathrm{C}-\mathrm{S}-\mathrm{H})$ dan kalsium aluminat hidrat (3 $\left.\mathrm{CaO} \cdot \mathrm{Al}_{2} \mathrm{O} 3.3 \mathrm{H}_{2} \mathrm{O}\right)$ bereaksi dengan ion-ion asam maka akan menghasilkan gipsum $\left(\mathrm{CaSO}_{4} \cdot 2 \mathrm{H}_{2} \mathrm{O}\right)$ dan kalsium sulfoaminate $\left(3 \mathrm{CaO} \cdot \mathrm{Al}_{2} \mathrm{O}_{3} \cdot 3 \mathrm{CaSO}_{4} \cdot 31 \mathrm{H}_{2} \mathrm{O}\right)$ atau kristal ettringite. Menurut Goyal et al. [17], kerusakan mortar atau beton diakibatkan oleh kristal ettringite yang mengisi pori-pori mortar atau beton sehingga dapat menyebabkan keretakan pada beton.

\section{Beton di lingkungan gambut}

Lingkungan gambut memiliki air permukaan dengan pH 3-5 dan berwarna coklat kehitaman yang korosif dan dapat melarutkan kalsium pada mortar dan beton. Berdasarkan penelitian terdahulu, mortar dan beton yang dibuat menggunakan bahan pengikat Ordinary Portland Cement (OPC) umumnya mengalami penurunan kualitas setelah direndam di dalam air gambut dalam waktu tertentu [5,6]. Akan tetapi penggunaan bahan tambah bersifat pozzolanik dapat meningkatkan ketahanan beton di lingkungan gambut. Penelitian terdahulu oleh Hutapea et al. [4] menggunakan air biasa sebagai air pencampur dan larutan asam sulfat dan air gambut sebagai air perendam. Hasil penelitian menunjukkan bahwa kuat tekan mortar PCC dan abu sawit yang direndam dalam air gambut meningkat. Penggunaan semen PCC dan abu sawit untuk beton di kanal gambut meskipun menggunakan air biasa sebagai air pencampur tetap meningkatkan kekuatan beton [5].

Penggunaan air gambut sebagai air pencampur beton di lapangan juga sering terjadi meskipun air gambut tidak memenuhi syarat air minum yang layak untuk pembuatan beton. Penelitian Rosani [18] yang menggunakan air gambut sebagai air pencampur dan air biasa sebagai air perawatan menunjukkan bahwa faktor air semen atau mutu beton mempengaruhi ketahanan beton di lingkungan gambut. Rinanda et al. [11] memperbaiki kualitas air gambut menggunakan 0,04 g/l kapur tohor dalam $1000 \mathrm{ml}$ air sehingga $\mathrm{pH}$ air gambut meningkat dan dapat digunakan sebagai air pencampur beton. Air perawatan yang digunakan adalah air gambut di 
kanal. Beton dengan air pencampur yang dicampur kapur tohor memiliki kekuatan tekan lebih tinggi dibandingkan beton yang menggunakan air gambut tanpa zat aditif.

\section{METODE PENELITIAN}

\section{Bahan}

Semen Portland tipe I, yakni OPC dan PCC digunakan sebagai bahan pengikat beton. Berbeda dengan semen OPC, pada semen PCC ditambahkan bahan pozzolanik seperti slag untuk meningkatkan ketahanan di lingkungan agresif. Tabel 1 menunjukkan komposisi semen OPC dan PCC yang digunakan dalam penelitian ini.

Tabel 1. Karakteristik Portland Cement Composite (PCC) produksi PT. Semen Padang

\begin{tabular}{|l|c|c|}
\hline \multirow{2}{*}{ Oksida (\%) } & \multicolumn{2}{|c|}{ Tipe semen } \\
\cline { 2 - 3 } & $\begin{array}{c}\text { Ordinary Portland } \\
\text { Cement/OPC [19] }\end{array}$ & $\begin{array}{c}\text { Portland Composite } \\
\text { Cement/PCC [20] }\end{array}$ \\
\hline $\mathrm{SiO}_{2}$ & 20,92 & 23,04 \\
\hline $\mathrm{Al}_{2} \mathrm{O}_{3}$ & 5,49 & 7,40 \\
\hline $\mathrm{Fe}_{2} \mathrm{O}_{3}$ & 3,78 & 3,36 \\
\hline $\mathrm{MgO}$ & - & 0,63 \\
\hline $\mathrm{CaO}$ & 65,21 & 57,38 \\
\hline $\mathrm{Na}_{2} \mathrm{O}$ & 0,52 & 0,52 \\
\hline $\mathrm{K}_{2} \mathrm{O}$ & - & - \\
\hline $\mathrm{TiO}_{2}$ & - & - \\
\hline $\mathrm{MnO}$ & - & - \\
\hline $\mathrm{P}_{2} \mathrm{O}_{5}$ & - & - \\
\hline $\mathrm{SO}_{3}$ & - & 1,78 \\
\hline $\mathrm{Lain}_{2}$-lain & 4,60 & 5,89 \\
\hline
\end{tabular}

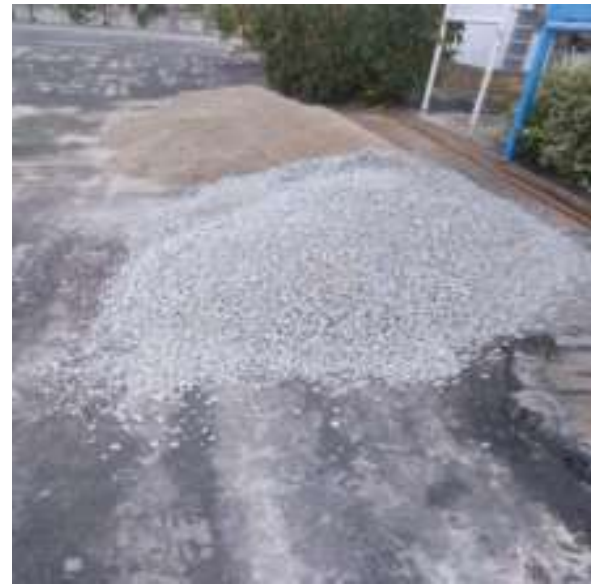

Gambar 2. Agregat kasar dan halus Tanjung Balai Karimun.

Gambar 2 menunjukkan agregat yang digunakan. Pada penelitian ini digunakan agregat halus dan agregat kasar dari Tanjung Balai Karimun, Provinsi Kepulauan Riau. Berdasarkan hasil pengujian karakteristik agregat halus, diperoleh data berat volume agregat halus sebesar $1,61 \mathrm{gr} / \mathrm{cm}^{3}$, kadar air 0,4\%, dan berat jenis 2,59. Kadar organik pasir tidak tinggi. Sedangkan agregat kasar memiliki berat jenis 2,64, kadar air 0,25\%, keausan 34,44\% dan berat volume $1,52 \mathrm{gr} / \mathrm{cm}^{3}$.
Air yang digunakan dalam penelitian ini adalah air gambut dari Kabupaten Bengkalis, dengan $\mathrm{pH} 3$ 5. Penambahan kapur tohor sebesar $0,05 \mathrm{gr} / \mathrm{liter}$ pada air gambut dan dilarutkan selama 10 menit menghasilkan $\mathrm{pH}$ sebesar 7,0 sehingga memenuhi persyaratan SNI 03-2847-2002 [14]. Gambar 3 memperlihatkan perubahan $\mathrm{pH}$ air gambut, yakni sebelum diberi kapur tohor memiliki $\mathrm{pH}=3,65$ dan setelah diberi kapur tohor $\mathrm{pH}$ menjadi 7,0.
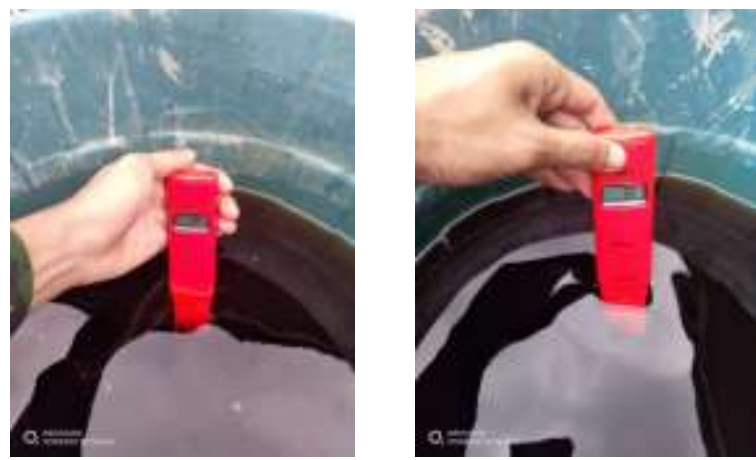

Gambar 3. pH air gambut (a) sebelum diberi kapur=3,65 dan (b) setelah diberi kapur $=7,0$

\section{Komposisi Campuran Beton}

Pada penelitian ini digunakan dua campuran beton, yakni OPC dan PCC dengan kuat tekan rencana $20 \mathrm{MPa}$. Tabel 2 memperlihatkan campuran beton OPC dan PCC yang dihitung berdasarkan SNI 03-2834-2000 [21].

Tabel 2. Komposisi material beton per $\mathrm{m}^{3}$

\begin{tabular}{|l|c|c|c|c|}
\hline $\begin{array}{c}\text { Tipe } \\
\text { semen }\end{array}$ & Air $(\mathrm{kg})$ & $\begin{array}{c}\text { Semen } \\
(\mathrm{kg})\end{array}$ & $\begin{array}{c}\text { Agregat } \\
\text { halus }(\mathrm{kg})\end{array}$ & $\begin{array}{c}\text { Agregat } \\
\text { kasar } \\
(\mathrm{kg})\end{array}$ \\
\hline OPC & 181,86 & 339,45 & $831 ., 6$ & 1009,33 \\
PCC & 189,38 & 331,93 & 831,36 & 1009,33 \\
\hline
\end{tabular}

\section{Pembuatan Benda Uji}

Benda uji direncanakan memiliki kuat tekan rencana sebesar $20 \mathrm{MPa}$. Benda uji berbentuk silider dengan dimensi 150x300mm. Terdapat empat macam campuran yaitu OPC (air pencampur adalah air gambut), OPC-K (OPC dengan air pencampur air gambut + 0,05 g/l kapur tohor), PCC (air pencampur air gambut), dan PCC-K (PCC dengan air pencampur air gambut+ $0,05 \mathrm{~g} / \mathrm{l}$ kapur tohor). Benda uji untuk masing-masing campuran dibuat tiga buah. Total benda uji untuk semua campuran berjumlah 96 buah.

Pembuatan benda uji dilakukan dengan mencampurkan bahan-bahan kering seperti agregat kasar, agregat halus, semen dan air. Air pencampur yang digunakan berupa air gambut tanpa kapur tohor dan diberi kapur tohor untuk kedua jenis semen OPC dan PCC. Setelah benda uji dicetak, kemudian dilakukan uji slump mengikuti standar SNI 1972: 2008 [22]. Nilai slump semua campuran diperoleh sebesar 70-120mm. 
Benda uji yang telah dicetak kemudian sehari kemudian direndam di saluran air terbuka hingga saat pengujian kuat tekan dan porositas pada umur 28, 91, 120 dan 150 hari. Gambar 4 memperlihatkan lokasi tempat perendaman benda uji di dalam saluran terbuka di kota Bengkalis. Aliran air dalam saluran selalu memiliki ketinggian cukup konsisten selama masa perendaman sampel.

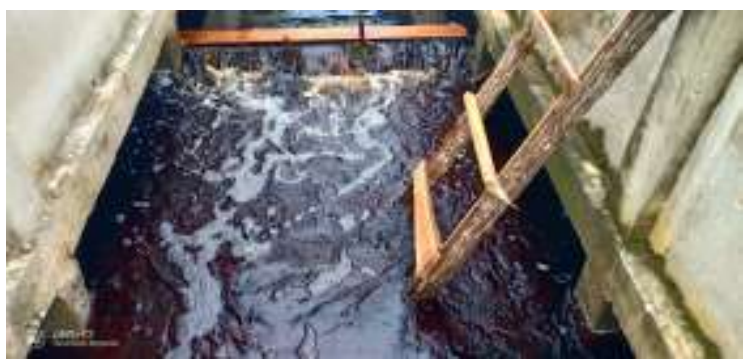

Gambar 4. Saluran terbuka tempat perendaman benda uji.

\section{HASIL DAN PEMBAHASAN}

\section{Kuat tekan}

Gambar 5 memperlihatkan perubahan kuat tekan beton OPC dan OPC-K yang menggunakan air gambut sebagai air pencampur tanpa dan dengan zat aditif lalu direndam dalam air gambut hingga umur 150 hari. Beton OPC-K merupakan beton yang dibuat menggunakan air pencampur ditambah kapur tohor. Pada gambar dapat dilihat bahwa terjadi kenaikan kuat tekan benda uji secara bertahap hingga umur 91 hari, lalu menurun hingga umur 150 hari. Penurunan kekuatan tekan beton juga terjadi pada beton OPC-K sebesar 12,29\% hingga beton berumur 120 hari sebelum terjadi kenaikan kuat tekan kembali sebesar 7,69\% pada umur 150 hari.

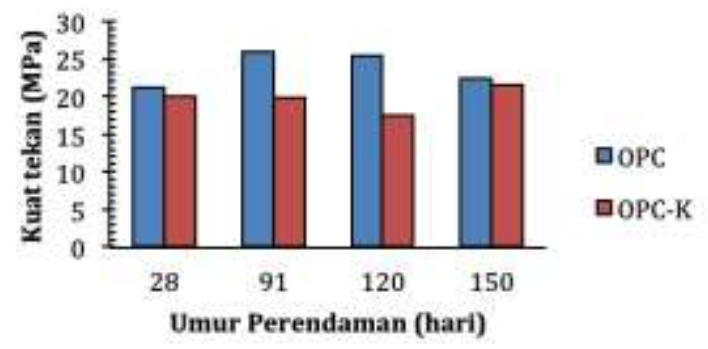

Gambar 5. Perubahan kuat tekan benda uji OPC dan OPC-K setelah direndam di air gambut hingga umur 150 hari.

Pada beton OPC, kekuatan beton menurun karena terjadi reaksi pelarutan kalsium oleh asam organik gambut dalam beton. Penurunan kuat tekan beton OPC sebesar $19,63 \%$ terjadi setelah 91 hari dan secara konsisten terus menurun meski hanya sebesar 5,21\% pada umur 150 hari. Hal serupa juga ditemukan oleh Olivia et al. [5] pada beton yang menggunakan air pencampur air biasa tetapi direndam di dalam air gambut setelah dirawat dalam air biasa selama 28 hari. Penurunan kuat tekan beton
OPC lebih signifikan dibandingkan beton menggunakan bahan tambah seperi abu sawit.

Penggunaan kapur tohor dalam air pencampur tidak memberikan dampak positif pada beton OPC$\mathrm{K}$ hingga umur 120 hari. Kapur tohor dapat meningkatkan $\mathrm{pH}$ tetapi tidak memperbaiki reaksi hidrasi semen saat beton berumur 28 hingga 120 hari. Reaksi air gambut meskipun telah diberi kapur tohor tetap melemahkan ikatan awal hidrasi semen sehingga kekuatan beton OPC-K terus menurun. Hal ini menunjukkan bahwa penggunaan air gambut yang diperbaiki dengan kapur tohor tidak dapat memperbaiki kekuatan beton OPC.

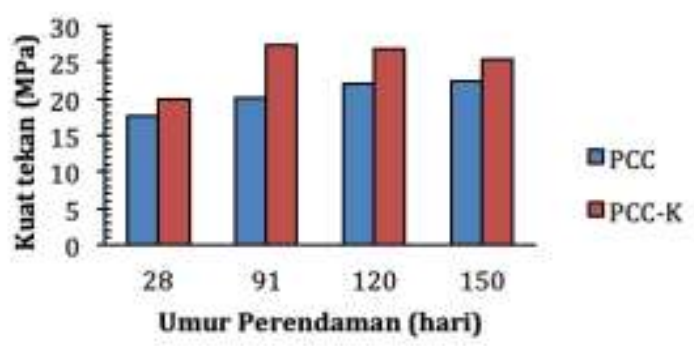

Gambar 6. Perubahan kuat tekan benda uji OPC dan OPC-K setelah direndam di air gambut hingga umur 150 hari.

Gambar 6 menunjukkan perubahan kuat tekan beton PCC dan PCC-K pada umur 28 hingga 150 hari. Pada beton PCC dapat dilihat terjadi kenaikan kuat tekan secara bertahap selama umur perendaman sebesar $13,85 \%, 24,25 \%$ dan $26,46 \%$. Peningkatan kekuatan tekan beton PCC setelah umur 120 hari cukup signifikan dibandingkan umur awal. Beton PCC mengandung bahan pozzolanik yang kaya silikat sehingga hasil reaksi berupa kalsium silikat hidrat dapat membantu memperbaiki fase mikrostruktur dan meningkatkan kekuatan beton. Hal ini telah diperkuat oleh [4,5] karena beton semen PCC tidak menunjukkan penurunan kekuatan meski telah direndam dan dicampur dengan air gambut selama 150 hari. Oleh karena itu, penggunaan beton dari semen PCC lebih disarankan untuk lingkungan gambut karena ketahanannya di lingkungan agresif.

Sedangkan pada beton PCC-K terjadi kenaikan kuat tekan yang sangat signifikan dari umur 28 hingga 91 hari sebesar 33,97\%, kemudian secara bertahap menurun menjadi $27,51 \%$ setelah direndam di air gambut pada umur 150 hari. Air gambut yang diberi kapur tohor sebagai air pencampur dapat memperbaiki kekuatan beton setelah umur 28 hari. Hal ini kemungkinan disebabkan oleh campuran semen PCC dengan bahan pozzolanik, sehingga penggunaan air gambut bercampur kapur tohor dapat meningkatkan kuat tekan lebih besar dari beton PCC pada umur 91 hari. Setelah umur 91 hari, terdapat penurunan kuat tekan beton PCC-K meskipun tidak begitu signifikan. Meski penggunaan kapur tohor untuk menaikkan $\mathrm{pH}$ air gambut, tetapi pengaruhnya hanya untuk menaikkan kuat tekan tetapi tidak dapat 
mempertahankan kekuatan yang terus menurun secara bertahap. Hal ini perlu dikaji lebih lanjut karena pada beton dapat terjadi ikatan produk hidrasi yang tidak cukup kuat dan mudah rusak setelah beberapa lama terendam dalam air gambut. Meski demikian, penambahan aditif tersebut dapat meningkatkan kekuatan pada umur awal sehingga tetap berdampak positif pada beton.

\section{Porositas}

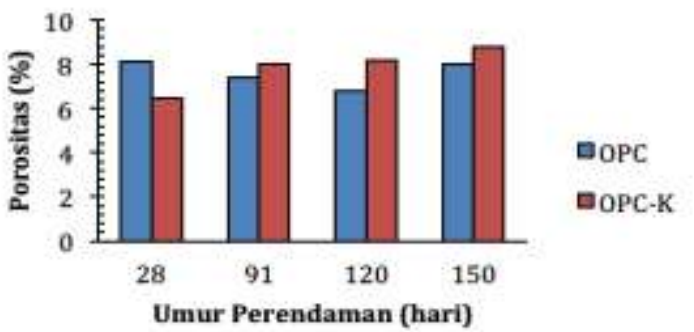

Gambar 7. Perubahan porositas benda uji OPC dan OPC-K setelah direndam di air gambut hingga umur 150 hari.

Gambar 7 memperlihatkan porositas benda uji OPC dan OPC-K setelah direndam dalam air gambut selama 150 hari. Perubahan porositas yang fluktuatif dapat dilihat pada beton OPC karena terjadi penurunan sekitar 16,36\% hingga umur 120 hari sebelum naik kembali sebesar $1,23 \%$ pada umur 150 hari. Sama seperti pada kuat tekan, porositas dipengaruhi oleh air pencampur beton. Oleh karena beton OPC menggunakan air gambut sebagai air pencampur, maka air gambut tersebut dapat langsung mempengaruhi proses pengurangan pori pada matriks semen dengan produk hasil hidrasi. Hal ini telah dijelaskan oleh Kazemian et al. [23] yang melaporkan perlambatan reaksi menghasilkan produk hidrasi saat gambut distabilisasi dengan semen.

Penggunaan beton OPC-K dicampur dengan air gambut dan kapur tohor menghasilkan porositas lebih rendah daripada beton OPC pada umur 28 hari. Akan tetapi porositas meningkat menjadi $1,35 \%$ dan 8\% pada umur 91 dan 150 hari. Pada penelitian ini terlihat bahwa peningkatan $\mathrm{pH}$ dengan kapur tohor tidak selalu memiliki dampak positif pada porositas beton dalam jangka panjang. Sebenarnya tidak terjadi perbedaan nilai porositas yang besar antara campuran OPC dan OPC-K pada tiap umur pengujian. Hanya saja porositas beton OPC-K terus meningkat menjadi $8 \%$ pada umur 150 hari. Proses kimia yang terdapat di dalam beton OPC-K menjadikan matriks yang terbentuk cukup kuat meskipun memiliki kuat tekan tinggi pada umur 150 hari. Akan tetapi porositas juga meningkat sebesar $8 \%$ karena matriks OPC-K tersebut barangkali memiliki rongga-rongga dari material organik pada gambut yang dapat menjadikan beton lebih porous daripada beton OPC. Temuan serupa pernah dikonfirmasi oleh Borger [9] yang menggunakan air selokan tanpa perawatan sehingga partikel padat pada air limbah membuat beton memiliki rongga yang banyak dan lebih porous dari beton dengan air bersih sebagai air pencampur. Hal ini perlu dikaji lebih lanjut perbaikan kualitas air gambut dengan kapur tohor dapat meningkatkan $\mathrm{pH}$, tetapi kandungan organik pada air gambut kemungkinan tetap berkontribusi dalam pembentukan pori pada matriks beton tersebut.

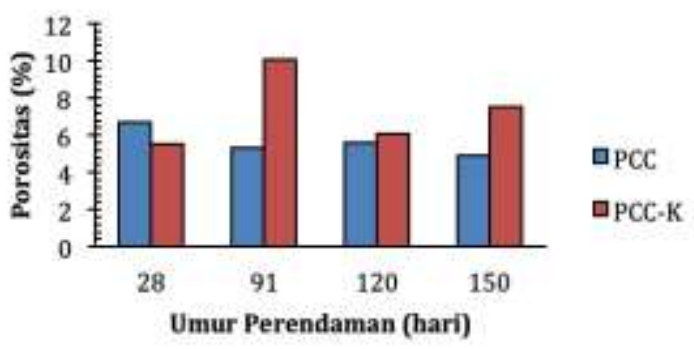

Gambar 8. Perubahan porositas benda uji PCC dan PCC-K setelah direndam di air gambut hingga umur 150 hari.

Gambar 8 memperlihatkan perubahan porositas beton PCC dan PCC-K setelah direndam dalam air gambut pada umur 28-150 hari. Pada gambar dapat dilihat bahwa umumnya porositas beton fluktuatif, meskipun terdapat trend berbeda antara beton PCC dan PCC-K. Beton PCC memperlihatkan trend porositas menurun, sedangkan trend pada beton PCC-K cenderung terjadi peningkatan porositas selama perendaman di air gambut. Beton PCC menggunakan air gambut tanpa tambahan kapur tohor memiliki porositas yang lebih rendah dibandingkan beton PCCK. Hal ini dapat disebabkan karena reaksi pozzolanik pada beton PCC secara perlahan terjadi dan membantu memperbaiki pori yang terdapat dalam beton PCC. Air gambut tidak memberikan pengaruh signifikan pada pembentukan pori beton PCC, sehingga beton PCC memiliki porositas lebih rendah yang cenderung menurun dengan pertambahan waktu perendaman.

Pada beton PCC-K, porositas yang terjadi cukup fluktuatif tetapi cenderung meningkat selama beton direndam. Penggunaan kapur tohor dalam dosis tertentu sebenarnya dapat memperbaiki kinerja beton yang direndam dalam air gambut. Pada kenyataannya, penambahan kapur sebagai aditif ditujukan untuk memperbaiki $\mathrm{pH}$ air gambut, akan tetapi kapur tambahan tersebut tampaknya memiliki reaksi tersendiri dengan air gambut sehingga berkontribusi terhadap peningkatan porositas. Meskipun belum pernah dikaji sebelumnya, penggunaan dosis kapur tohor untuk memperbaiki kualitas air pencampur sebenarnya perlu dikaji lebih lanjut karena tidak hanya berpengaruh pada $\mathrm{pH}$ air saja. Penggunaan kapur tohor dengan dosis $50 \mathrm{mg} / \mathrm{l}$ dalam penelitian sebenarnya cukup rendah, tetapi pengaruh dalam skala mikrostruktur untuk beton OPC dan PCC yang dibuktikan dengan nnilai porositas membuktikan bahwa penambahan kapur tohor untuk mendapatkan hasil optimal memerlukan penelitian lebih lanjut. 
Gambar 9 memperlihatkan benda uji yang telah diangkat dari tempat perendaman. Secara umum benda uji berwarna kecoklatan setelah direndam dalam air gambut. Permukaan benda uji memiliki tekstur kasar karena agregat halus banyak terlepas dari selimut beton. Biasanya beton yang direndam di air mengalir akan mengalami kondisi demikian karena aliran air menggerus permukaan beton. Akan tetapi, karena perendaman dilakukan pada air gambut, maka reaksi antara beton dengan air gambut menjadi penentu awal dari kerusakan beton, lalu tergantung mutu beton maka kerusakan akan dapat dipercepat oleh aliran air yang abrasif.

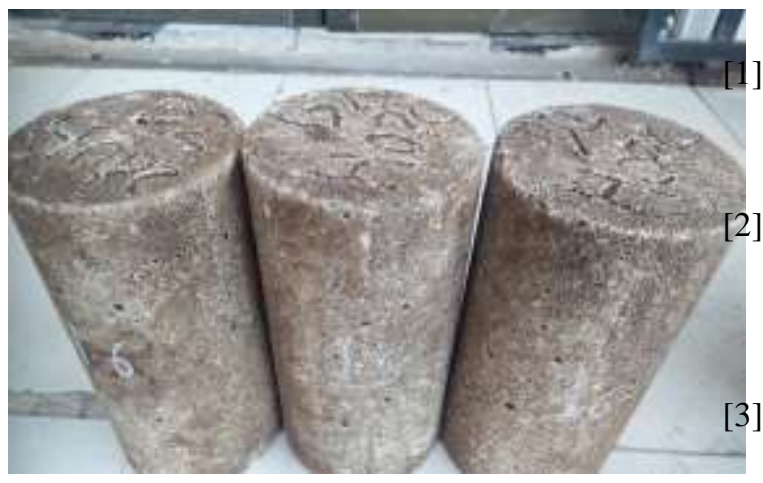

Gambar 9. Benda uji setelah direndam di saluran air gambut.

Pada penelitian ini digunakan beton OPC dan PCC dengan kekuatan rencana sebesar $20 \mathrm{MPa}$ pada umur 28 hari. Penggunaan mutu beton perlu diperhatikan untuk aplikasi struktur di tanah gambut. Hasil penelitian bermanfaat sebagai titik awal untuk memperbaiki potensi kerusakan struktur karena air gambut bersifat asam. Selain tipe semen, dosis kapur tohor, dari penelitian ini dapat dilihat bahwa kualitas beton juga akan menentukan ketahanan beton di lingkungan gambut dalam jangka panjang.

\section{KESIMPULAN}

Berdasarkan hasil penelitian mengenai kuat tekan dan porositas beton menggunakan air pencampur dari air gambut dengan kapur tohor dapat diambil beberapa kesimpulan. Kapur tohor sebesar $50 \mathrm{mg} / \mathrm{l}$ dapat digunakan untuk meningkatkan $\mathrm{pH}$ air gambut dari 3,65 menjadi $\mathrm{pH} 7,0$. Air pencampur menggunakan air gambut yang diperbaiki dengan kapur tohor secara umum meningkatkan $\mathrm{pH}$ tetapi tidak berdampak positif terhadap peningkatan kekuatan tekan beton OPC (OPC-K). Trend yang sama ditunjukkan oleh nilai porositas beton OPC-K karena porositas cenderung meningkat dengan masa perendaman dalam saluran air gambut. Pada beton PCC$\mathrm{K}$ terjadi peningkatan nilai kuat tekan dibanding beton $\mathrm{PCC}$, tetapi trend tersebut terus menurun dengan pertambahan umur perendaman. Porositas beton PCC-K lebih tinggi dibandingkan beton PCC, dan mengikuti trend beton OPC-K. Hal ini menunjukkan bahwa penggunaan kapur tohor untuk memperbaiki air gambut memerlukan dosis yang tepat sehingga menimbulkan reaksi sampingan lain dengan kapur tambahan tersebut. Selain itu, penggunaan air gambut yang dicampur dengan kapur tohor juga memerlukan zat lain sehingga kandungan organik tidak menyebabkan timbulnya rongga-rongga pada beton dan meningkatkan porositas. Meski demikian, persentase penurunan kuat tekan dan peningkatan porositas masih tergolong cukup rendah untuk beton OPC dan PCC dengan air pencampur yang telah diperbaiki, sehingga secara umum dapat disimpulkan bahwa penggunaan kapur tohor pada air gambut dapat meperbaiki kuat tekan dan porositas beton OPC dan PCC yang terpapar air gambut di wilayah Kabupaten Bengkalis.

\section{DAFTAR PUSTAKA}

Nasrul, B, Penyebaran dan Potensi Lahan Gambut di Kabupaten Bengkalis untuk Pengembangan Pertanian, Jurnal Agroteknologi, Vol. 1 No. 1, Agustus 2010.

Eglinton, M, Resistance of concrete to destructive agencies. In Hewlett, P.C. (ed). Lea's Chemistry of Cement and Concrete. Amsterdam: Elsevier Science \& Technology Books.

Riely, J.O, and Page, S.E, (eds), Biodiversity and Sustainable of Tropical Peat and Peatland, Cardigan: Samara Publication, 1997.

[4] Olivia, M, Hutapea, U.A, Sitompul, I.R, Darmayanti, L, Kamaldi, A, and Djauhari, Z, Resistance of plain and blended cements exposed to sulfuric acid solution and acidic peat water: A Preliminary Study, 2014, The $6^{\text {th }}$ International Conference of Asian Concrete Federation, Seoul, 2014.

[5] Olivia, M, Pradana, T, Sitompul, I.R, 2016, Properties of plain and blended cement concrete immersed in an acidic peat water canal, Sustainable Civil Engineering Structure and Construction Material, Denpasar, 2016.

[6] Olivia, M, Darmayanti, L, Kamaldi, A, Djauhari, Z, Kuat tekan beton dengan semen campuran limbah agro-industri di lingkungan asam, $2^{\text {nd }}$ ACE National Conference 2015, Padang, Sumatra Barat, 2015.

[7] Mulyono, T, Teknologi Beton, Yogyakarta: Penerbit Andi, 2007.

[8] Kumar, S, Influence of water quality on the strength of plain and blended cement concretes in marine environments. Cement and Concrete Research Vol. 3, 2000.

[9] Borger, J., Carrasquillo, R.L, Fowler, D.W, Use of recycled wash water and returned plastic concrete in the production of fresh concrete, Advanced Cement Based Materials, Vl. 1, 1994.

[10] Cebeci, O.Z, Saatci, A.M, Domestic sewage as mixing water in concrete, ACI Materials Journal, Vol. 86, 1989.

[11] Rinanda, R, Olivia, M, Saputra, E, Kuat tekan dan porositas beton OPC dan OPC POFA dengan air pencampur gambut menggunakan 
bahan aditif, Jurnal Online Mahasiswa Fakultas Teknik, Vol. 4, No. 2, 2017.

[12] Nugraha, P, Antoni, Teknologi Beton, Yogyakarta: Penerbit Andi, 2007.

[13] ACI Committee 201, Guide to Durable Concrete, Farmington Hills: American Concrete Institute, 2008.

[14] SNI 03-2847-2002, Standar Nasional Indonesia, Tata Cara Perhitungan Struktur Beton. Badan Standardisasi Nasional, Jakarta, 2002.

[15] Duraisamy, Y, Huat, B.B.K, Aziz, A.A, Methods of utilizing tropical peat land for housing scheme, American Journal of Environmental Sciences, Vol. 3, 2007.

[16] CEB, Durable Concrete Structures Design Guide, Lausanne: Comite Euro-International Du Beton, 1992.

[17] Goyal, S, Kumar, M, Sidhu, D.S, Bhattacharjee, $\mathrm{B}$, Resistance of mineral admixture concrete to acid attack, Journal of Advanced Concrete Technology, Vol. 7, 2009.
[18] Rosani, A.M, Pengaruh penggunaan air gambut Tembilahan terhadap kuat tekan beton, Tugas Akhir Prodi S1 Teknik Sipil, Universitas Riau.

[19] Salain, I.M.A.K, Karakteristik Semen Portland, Jurnal Teknologi dan Kejuruan, Vol. 32, 2009.

[20] Brosur Spesifikasi Semen PCC, Padang: Semen Padang.

[21] SNI 03-2834-2000, Tata Cara Perencanaan Campuran Beton Semen Portland dengan Abu Terbang, Badan Standardisasi Nasional, Jakarta, 2000.

[22] SNI 1972:2008. Cara Uji Slump Beton. Badan Standardisasi Nasional, Jakarta, 2008.

[23] Kazemian, S, Prasad, A, Huat, B.B.K, Baza, J.B, Mohammed, T.A, Aziz, F.N.A, Effect of aggressive $\mathrm{pH}$ media on peat treated by cement and sodium silicate grout. Journal of Central South University, Vol. 18, 2011. 